\title{
PEREGRINE RELEASE IN GRAND \\ TETON NATIONAL PARK
}

\author{
William Burnham \\ The Peregrine Fund Incorporated \\ Fort Collins, CO
}

Peregrine falcons were never numerous relative to most other avian species, however, many historic nesting sites are known. In the Rocky Mountains approximately $50 \%$ of these sites exist in National Parks and Monuments. This year The Peregrine Fund, in cooperation with the Wyoming Game and Fish, Grand Teton National Park, and Bridger-Teton National Forest began restoration of the species in the Tetons. Three release sites were selected on high cliffs overlooking Jackson and Phelps Lakes in Grand Teton National Park.

\section{Procedure}

The releases were accomplished by hacking which involves caring for young falcons at a selected site with no adult falcons and allowing them to grow and learn to fly in the belief that they will associate to the area and return there to breed. The hack boxes consisted of a $5^{\prime} \times 4^{\prime} \times 3^{\prime}$ plywood box having a barred front and gravel floor. Each box was equipped with a remote feeding shute so young did not associate food with man. The barred fronts are removed when the young are old enough to fly.

\section{$\underline{\text { Results }}$}

Eleven 35-day-old anatum peregrines were placed in the hack boxes. The last peregrine became independent and supplemental feeding stopped on September 15. Following removal of the bars on two of the hack boxes, golden eagles attacked the newly airborne peregrines. These attacks caused the loss of two young peregrines. If adult peregrines had been present, the eagles would have been driven off despite the fact that the young are defenseless when just learning to fly. The young peregrines flight capabilities develop very quickly and within 1 week they agressively pressure any intruding eagle, driving it away.

Many peregrine sitings were reported near Jackson Lake last summer and visitor enthusiasm seemed very high. As one visitor said, "To see the fastest, most courageous bird in the world chasing a small bird while outlined against the Grand Teton is something I shall never forget". The importance of the National Parks system to the recovery and future survival of the peregrine falcon can not be underestimated. The parks are an integral part of the total recovery effort. No 
other federally controlled lands hold the future promise through control and management that is possible in the National Parks system. By the parks becoming more involved they will provide the American public the opportunity to observe the peregrine falcon in its natural environment.

\section{Acknowledgements}

Special thanks is given to the Wyoming Game and Fish Department, Grand Teton National Park and the U.W.-N.P.S. Research Center for their cooperation and assistance. Thanks is also given to the Wyoming Chapter of the Safari Club International and the Rocky Mountain Conservation Fund, Inc. for their financial assistance. Additional assistance was provided by Senator John Turner, Tom Stroock and Scott Grieve. 